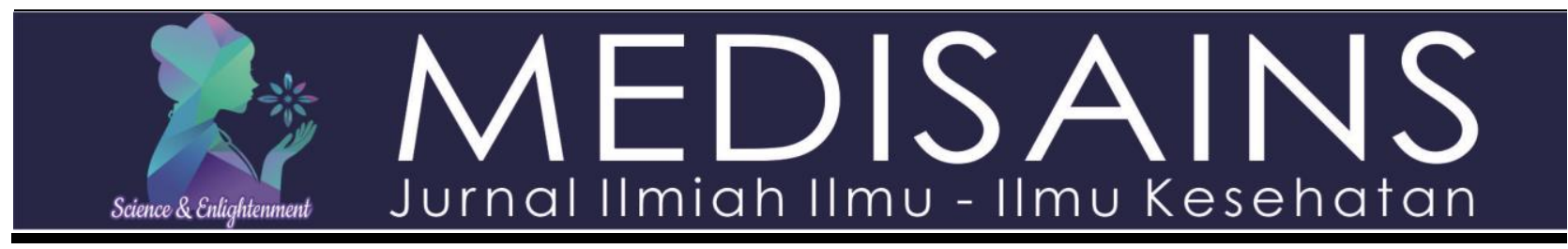

Original Article

\title{
Factors affecting resilience of drug abusers at correctional facilities
}

Sri Warsini 1, Arfiana Fani Astuti, Diana Nurlaila Sari, Pita Puji Lestari, Sherli Damara Pratiwi, Mahmasoni Masdar, Nur Ajie Prasetyo, Diah Fitri Indriati ${ }^{2}$, Carla Raymondalexas Marchira $^{3}$

${ }^{1}$ Mental Health and Community Nursing Department, Universitas Gadjah Mada, Yogyakarta

${ }^{2}$ School of Nursing, Universitas Gadjah Mada, Yogyakarta

${ }^{3}$ Psychiatric Department, Universitas Gadjah Mada, Yogyakarta

\section{ARTICLE INFORMATION}

Received: Agustus 19, 2019

Revised: Agustus 27, 2019

Available online: Oktober 01, 2019

\section{KEYWORDS}

Self Efficacy; Drug Users; Narcotics; Depression

\section{CORRESPONDENCE}

Phone: +62-274-545674

E-mail: sri.warsini@ugm.ac.id

\section{A B S T R A C T}

Background: Indonesia is currently facing a narcotics emergency as indicated by a drastic increase in the number of drug users and drug-related deaths. Rehabilitation does not guarantee recovery and relief from drugs. Even while undertaking rehabilitation, drug abusers may relapse. Resilience can prevent drug abusers from relapsing and help them overcome their problems. There has been a dearth of research focusing on factors affecting the resilience of drug abusers in Indonesia.

Objective: The objective of this research is to identify factors affecting the resilience of drug abusers at correctional facilities in the Special Region of Yogyakarta.

Methods: This is a cross-sectional design and was conducted in February 2017 at the Correctional Facility for Narcotics Cases Class IIA in Sleman and the Correctional Facility in Wirogunan. A total of 77 respondents were involved in this research by a consecutive sampling technique. The instruments used included the resilience questionnaire developed by Pertiwi based on Grotberg's theory, Beck Depression Inventory II, Satis-faction with Life Scale and Positive Affect Negative Affect Schedule, Isundariyana's stress instrument, Rosenberg Self-Esteem Scale (RSES), Zung Self Rating Anxiety Scale (ZSAS), General Self-Efficacy Scale, Life Orientation Test-Revised (LOT-R), and Difficulties in Emotion Regulation Scale (DERS). The data were analyzed by univariate, bivariate (Pearson and Spearman's Rank), and multivariate (linear regression) analyses.

Results: Out of the 8 factors examined (subjective well-being, optimism, selfesteem, emotion regulation, anxiety, stress, depression, and self-efficacy) and 2 demographic factors (age and occupational status), only self-efficacy ( $\beta=$ $1.063 ; p=0.13)$, optimism $(\beta=1.51 ; p=0.01)$, and self-esteem $(\beta=1.540 ; p=$ 0.009 ) affected resilience.

Conclusions: Self-efficacy, optimism, and self-esteem are modifiable factors that can influence the resilience of drug abusers.

\section{INTRODUCTION}

Currently, Indonesia is in the midst of confronting a narcotics emergency. The drug abuse prevalence and the amount of substances trafficked into the country are staggering. The number of cases, as unraveled by the National Narcotics Agency (BNN), has skyrocketed, from 102 cases in 2014 to 800 cases in $2016 .^{1}$
The Special Region of Yogyakarta is one of provinces in Indonesia for which drug trafficking is aimed, considering that this region is a student city flocked by grade students or university students who are the main targets of traffickers. The results of a 2014 national survey show that Yogyakarta occupied the fifth place with a total of $62,028 \mathrm{drug}$ abusers, who made up $2.37 \%$ of the population. ${ }^{2}$ Meanwhile, the data of drug-related criminal cases in Yogyakarta from the Yogyakarta Regional Police and Yogyakarta Narcotics Agency reveal that in 2014, there were 397 
drug-related criminal offences; 120 of which involved grade students and university students. ${ }^{3}$

The impacts of drug abuse are immense and highly systematic. Drugs not only cause physical and mental disorders for the users, but also upset family structures and threaten the state's stability. Thus, multiple attempts should be made to prevent wider drug trafficking and comprehensive handling should be rendered for drug abusers.

Indonesia's legal system categorizes drug abuse as a criminal act (Law No. 35 of 2009). ${ }^{4}$ Thus, drug abusers who are proven to have committed the crime will be imprisoned (in a correctional facility) to receive guidance. During the imprisonment, they will participate in rehabilitation programs. However, the rehabilitation programs taken do not guarantee that the drug abusers are completely substance-free. Relapse may always occur during or in the aftermath of the rehabilitation programs. Based on the data from the Yogyakarta Narcotics Agency, the relapse rate of drug addicts going through medical rehabilitation was $90 \%, 60-70 \%$ for those going through medical and social rehabilitation, and $40 \%$ for those going through medical and social rehabilitation and receiving post-rehabilitation treatment. ${ }^{3}$

Various factors can bring drug abusers to relapse. Afkar et $\mathrm{al}^{5}$ classified relapse causes into four major factors, namely individual, family, occupational, and economic factors. Another research indicated that drug relapse stressors include depression, curing program non-compliance, and life crisis. ${ }^{6}$ Drug abusers require an ability to remain clean and evade relapse. An individual's ability to successfully overcome hardship and adapt to different situations is termed resilience. Resilient individuals are able to control their emotion in facing stress or other negative feelings, wipe out the desire to use drugs again, and realize then avoid impulsive behavior related to drug use. ${ }^{7}$

To increase an abuser's resilience, it is necessary to first identify factors that may influence resilience. Resilience is affected by internal and external factors. Zolkoski and Bullock $^{8}$ state that biological factors (congenital defects) and environmental factors (poverty, parent's education, family conflict, negative life experience) are risk factors most influential to one's resilience. Meanwhile, protective factors in resilience include individual factors such as high intellectuality, optimism, self-efficacy, confidence, and self-esteem; family factors such as good parenting, socioeconomic status, and family support; and community factors such as good social relationship and active role in community organization. ${ }^{9}$ Some other factors that influence resilience in general are self-esteem ${ }^{10}$, stress, anxiety, depres$\operatorname{sion}^{11}$, self-efficacy, optimism, and emotion regulation. ${ }^{12}$

To date, there has been no published research paper in
Indonesia describing the level of resilience and factors affecting the resilience of drug abusers at correctional facilities. Previous research was conducted at a rehabilitation centre, and it is clear that correctional facilities and rehabilitation centres have different characteristics. Not only is it restrictive, a correctional facility also has such a condition that serves as a distinct stressor to abusers. For this reason, it is deemed necessary to conduct research for identifying the factors influencing the resilience of drug abusers at correctional facilities. By carrying out a multifactor analysis on the resilience of drug abusers, data on the factors and a thorough model related to the factors affecting the resilience of drug abusers, especially those in Yogyakarta, can be obtained. Hence, it is expected that this will contribute to the improvement of abusers' resilience. The aim of this research is to obtain a picture on the level of resilience of drug users at correctional facilities as well as the factors affecting resilience.

\section{METHOD}

\section{Study design}

This research is a correlational analytic study with a crosssectional design which was conducted in February of 2017 at two narcotics-related correctional facilities in Yogyakarta. The sample of this research was selected by a consecutive sampling technique. A total of 80 respondents were enrolled. The inclusion criteria employed in this research are as follows: 1) drug convicts for a minimum of 2 months; 2) aged 18 years or beyond; and 3) staying at the correctional facilities for more than 2 weeks. Respondents would be excluded from this research if they were found to demonstrate withdrawal symptoms or were not cooperative over the course of the study, have a history of mental disorders, or were having leaves. Three respondents did not complete the questionnaires and were declared to drop out, thus the data used were obtained from the remaining 77 respondents.

\section{Research instruments}

This research employed 9 instruments. The first instrument used was the resilience instrument developed by Pertiwi ${ }^{13}$, featuring the resilience components proposed by Gortberg ${ }^{14}$ (i.e., external support, inner strength, and interpersonal and problem-solving skills), which was later modified by Dewi ${ }^{15}$. Resilience levels were divided into two, namely low resilience $(x \leq 164)$ and high resilience $(x$ $>164)$. The results of the validity and reliability testing on the resilience instrument show that 54 of 64 question items were valid at an $r$ range of $0.312-0.636$ and a Cronbach's alpha of 0.940 .

The second instrument was an instrument for measuring stress developed by Isundariyana ${ }^{16}$, which was modified by the researchers according to Hawari's stress theory ${ }^{17}$. Stress levels were categorized into high stress $(x \geq 86)$, moderate stress $(55<x<86)$, and low stress $(x \leq 55)$. The 
results of the validity and reliability testing on the stress instrument conducted by the researchers show that 29 of 35 items were valid at a value range of $0.316-0.742$ and Cronbach's alpha of 0.901 .

There were two instruments used for measuring subjective well-being: 1) the Satisfaction with Life Scale developed by Pavot $\&$ Diener ${ }^{18}$, which used a seven point Likert scale and consisted of five questions and 2) the Positive Affect Negative Affect Schedule developed by Watson et al ${ }^{19}$ which consisted of 20 items. This research used validity and reliability testing, and for the resilience instrument, the Cronbach's alpha was 0.940 . As for the subjective wellbeing instruments, the Cronbach's alpha for the Satisfaction with Life Scale was 0.872 , for the positive affect 0.883 , and for the negative affect 0.822 .

Depression was measured using the Beck Depression Inventory II, which was adjusted to DSM-IV criteria. Depression levels were divided into four categories: minimal depression or normal condition (0-9), mild depression (1016), moderate depression (17-29), and severe depression (30-63). The results of the validity and reliability testing on the depression instrument conducted by the researcher show that 19 of 21 items were valid at a value range of $0.289-0.620$ and Cronbach's alpha of 0.882 .

The 10-item Rosernberg's Self-Esteem Scale (RSES) was used to measure self-esteem. Self-esteem levels were divided into two categories, namely high self-esteem ( $x>$ $26.11)$ and low self-esteem $(x<26.11)$. The results of the validity and reliability testing on the RSES conducted by the research using corrected item-total correlation show that 6 of 10 items were valid at a value range of $-0.142-$ 0.566 and Cronbach's alpha of 0.645 .

To measure anxiety, the 20 -item Zung Self-Rating Anxiety Scale (ZSAS) was used. The reliability testing results show that the Cronbach's alpha obtained was 0.940 . The 10item General Self-Efficacy Scale adapted by Palingii20 was used to measure self-efficacy. The Cronbach's alpha obtained was 0.844 . Meanwhile, to measure optimism, the Life Orientation Test-Revised (LOT-R) was used. This 10item instrument was developed by Scheier et al. ${ }^{21}$ and was employed by Simanjuntak ${ }^{22}$. The validity and reliability testing yield an $r$ value which fell anywhere between 0.266 and 0.525 and Cronbach's alpha of 0.563 . The last instrument used was the Difficulties Emotion Regulation Scale by Gratz \& Roemer ${ }^{23}$. From the validity and reliability testing on the instrument, $r$ value within the range of $0.316-$ 0.642 and Cronbach's alpha of 0.865 were obtained.

\section{Research Ethics}

Data collection in this research was carried out after receiving approval from the Ethics Committee of the Faculty of Medicine of Universitas Gadjah Mada.

\section{Data Analysis}

The data were analyzed using SPSS software version 21.0 for validity testing, reliability testing, normality testing, univariate analysis, bivariate analysis, and multivariate analysis. The univariate analysis in this research was used to gain a picture of the respondents' characteristics, a picture of the level of resilience, and a picture of the eight independent variables. The bivariate analysis was used to figure out the correlation between resilience and the eight independent variables as well as the demographic characteristic variables. Pearson's Correlation test, Spearman's Rank test, and unpaired t-test were carried out as part of the bivariate analysis. Meanwhile, the multivariate analysis used a multiple linear regression test with Forward method.

\section{RESULTS}

\section{Respondents' characteristics}

As many as 77 respondents from two correctional facilities were involved in this research. On average, the respondents were aged 30.1 years ( \pm 8.6 years). Male respondents were twice as many as the female ones. The majority of the respondents pursued education at general or vocational high schools, were of Javanese origin, were employees or self-employed, and had no illness history. The proportions of married and single respondents were more or less equal.

Generally, the respondents used more than 1 type of substance. Most respondents admitted that they used narcotics, psychotropic drugs, or other addictive substances and that they quitted less than one year ago. They used such substances for the first time at any time between 2000 and 2010. Some of the primary reasons for the respondents' use of drugs explored in this research were peer and association demand $(58.3 \%)$, life problems $(35 \%)$, and needs $(20.7 \%)$. Other reasons such as occupational demand, doping, family, medication, romantic partner, and environment had little influence on the respondents.

On average, the respondents had been staying at the correctional facility for 11.2 months and were to serve a sentence of 42.5 months, meaning that most of them were still serving a quarter of their sentence. Most of the respondents revealed that they never relapsed $(88.3 \%)$, never experienced drug withdrawal $(81.8 \%)$, and never went through rehabilitation (83.1\%).

\section{Resilience and Its Factors}

Most of the respondents at the Correctional Facility for Narcotics Cases Class IIA in Sleman and the Correctional Facility Class IIA in Yogyakarta had low resilience (58.4\%), self-esteem (57.1\%), and subjective well-being (50.6\%). They also had moderate depression (32.5\%) and stress $(62.3 \%)$. Yet, most of them had normal emotion regulation had high self-efficacy (97.4\%) and optimism (94.8\%). 
Table 1. Results of the multivariate test on the factors affecting resilience $(n=77)$

\begin{tabular}{|c|c|c|c|c|c|}
\hline Model & Variabel Independent & B & $\beta$ & $p$-value & $\begin{array}{c}95 \% \text { Confident } \\
\text { Interval }\end{array}$ \\
\hline 1 & $\begin{array}{l}\text { Constant } \\
\text { Self efficacy }\end{array}$ & $\begin{array}{l}98.48 \\
2.23\end{array}$ & 0.57 & $\begin{array}{l}0.000^{*} \\
0.000^{*}\end{array}$ & $\begin{array}{c}76.73 ; 120.23 \\
1.48 ; 2.97\end{array}$ \\
\hline 2 & $\begin{array}{l}\text { Constant } \\
\text { Self efficacy } \\
\text { Optimism }\end{array}$ & $\begin{array}{c}54.93 \\
1.62 \\
2.14\end{array}$ & $\begin{array}{l}0.41 \\
0.37\end{array}$ & $\begin{array}{l}0.001^{\star} \\
0.000^{\star} \\
0.000^{*}\end{array}$ & $\begin{array}{c}24.46 ; 85.40 \\
0.86 ; 2.37 \\
1.02 ; 3.27\end{array}$ \\
\hline 3 & $\begin{array}{l}\text { Constant } \\
\text { Self efficacy } \\
\text { Optimism } \\
\text { Self esteem }\end{array}$ & $\begin{array}{c}38.84 \\
1.06 \\
1.85 \\
1.54 \\
\end{array}$ & $\begin{array}{l}0.42 \\
0.32 \\
0.28 \\
\end{array}$ & $\begin{array}{l}0.017^{*} \\
0.013^{*} \\
0.001^{*} \\
0.009^{*}\end{array}$ & $\begin{array}{c}7.25 ; 70.44 \\
0.23 ; 1.90 \\
0.75 ; 2.95 \\
0.40 ; 2.68 \\
\end{array}$ \\
\hline
\end{tabular}

${ }^{*}$ Significant with $p<0.05 ;$ Adjusted $R$ Square 48. 3\%

To figure out whether resilience differs by demographic characteristics and drug abuse history, unpaired t-test was conducted. From the analysis, it can be concluded that resilience values only differed by age and occupational history. Adult respondents had higher resilience values than their teen and elderly counterparts $(p=0.017)$, and those who worked before getting imprisoned had higher resilience values than those who were unemployed $(p=0.001)$. Meanwhile, the results of the correlation tests using Pearson and Spearman's Rank tests show that all of the eight independent variables examined in this research (depression, emotion regulation, self-efficacy, self-esteem, anxiety, stress, optimism, subjective wellbeing) were correlated with the variable resilience $(p<0.005)$.

The variables which significantly influenced the respondents' resilience $(p<0.005)$ were qualified for the multivariate analysis. The variables included age, occupation, depression, emotion regulation, self-efficacy, self-esteem, anxiety, stress, optimism, and subjective well-being. The results of the multivariate analysis that was conducted using the Forward method (see Table 1 ) indicate that only self-efficacy $(\beta=0 ; p=0.013)$, optimism $(\beta=0.32 ; p=$ $0.001)$, and self-esteem $(\beta=0.28 ; p=0.009)$ were able to significantly affect the resilience of the drug abusers at the correctional facilities in Yogyakarta. The three variables affected the resilience of the drug abusers at $48.3 \%$.

\section{DISCUSSION}

The resilience of the drug abusers in this research was low. According to Harvey ${ }^{24}$, convicts with low resilience tend to have stress, anxiety, and depression, tend to be individualistic, lack confidence, have underdeveloped selfpotential, and face difficulties adapting to prison situation. On the contrary, individuals with high resilience will be able to adapt to the ongoing changes, lowering the arising stress and enabling them to respond to psychological and physiological stress adaptively. ${ }^{25}$

The low resilience in the respondents may be explained by the respondents' being new convicts who were still serving their sentence for one year or less. Williams ${ }^{26}$ elaborates that the situation that influences convicts' psychological state the most is the situation they are under early in their sentence term. Their convict status also causes them to feel depressed, lose the fighting spirit in life, regret their mistakes, and ponder over manifold possible negative events befalling them and their family. ${ }^{27}$

Everall ${ }^{28}$ states that resilience is closely related to the ability to communicate something using the right language, both verbally and nonverbally. Meanwhile, life in prison may spoil an individual's psychological condition, for example, by stripping their freedom to have aspirations and to communicate off from them. Bartol states that while convicts are spending their time in the prison, they are given time restriction to meet and communicate with their loved ones, including their family, whereas family support is one of the factors that can help them improve their resilience. ${ }^{29}$

Based on the Trans-theoretical model concept, it can be concluded that most of the respondents in this research had just entered the contemplation phase since it was only less than a year since they quitted using drugs, as stated by some respondents. Contemplation phase is a phase in which an individual contemplates the impacts of a matter and intends to change but not in the near future..$^{30}$

The results of this research are different from those of two previous studies on resilience among drug abusers. The research conducted by Pertiwi ${ }^{13}$ at BNN Lido revealed that most of the respondents (69.4\%) had moderate resilience, while Dewi's ${ }^{15}$ research that was conducted at PSPP Pamardi Putra Yogyakarta indicated that the resilience level of the majority of the respondents was high. There are at least two reasons for the difference in the results of the aforementioned studies: sample characteristics and technique for categorizing the instrument scores. In the previous two studies, the respondents had taken drug rehabilitation programs, while in the present study; most respondents $(82.3 \%)$ had not taken part in any rehabilitation program. The respondents in Pertiwi's study ${ }^{13}$ were mostly in the primary (green) phase, meaning that they had been taking a rehabilitation program for 6-9 months, while most 
of the respondents in Dewi's ${ }^{15}$ study were in the re-entry phase, meaning that they had been taking a rehabilitation program for $>12$ months.

The results are also different from those of the study by Zamani et $\mathrm{al}^{31}$ that was undertaken at a rehabilitation center in Malaysia, with most of the respondents $(51.1 \%)$ having high resilience. The difference is related to the different sample characteristics. In the previous research, the respondents mostly had taken drug rehabilitation programs, while in this research; most respondents (82.3\%) had not taken any rehabilitation program. As stated by Zamani et $\mathrm{al}^{31}$, a rehabilitation program that covers counseling and spiritual activities may contribute to resilience improvement. How long the residents have been staying at the rehabilitation center and which rehabilitation phase the residents were in will influence the residents' levels of resilience. ${ }^{13}$

Second, the different results might be related to the categorization technique used. The previous two studies divided resilience levels into high, moderate, and low, while this research categorized resilience levels only into high and low. The researchers justified this categorization by basing on the fact that there has yet been any expert who put resilience onto moderate level. The categorization into three levels was only relevant for statistical processing purpose.

The average value of the respondents' resilience in this study (mean $=163$ ) may be categorized into high resilience in the previous studies. The higher average resilience value in this research was yielded on the account that the number of valid items of the resilience questionnaire used in this research was higher than that of the previous two studies, namely 54 of a total of 64 (84.3\%). In Dewi's ${ }^{15}$ research, only 45 out of 64 items were valid $(70 \%)$, while in Pertiwi's ${ }^{13}$ research in 2011 , despite a higher percentage $(87.3 \%)$, the number of valid items in the questionnaire used was lower (48 items).

Based on the results of the multivariate analysis, the three primary factors affecting the resilience of drug abusers were optimism, self-efficacy, and self-esteem. Optimism has been proven to contribute to resilience. According to Siebert ${ }^{32}$, those who have high resilience hope that things go well or adopt an optimistic attitude and have robust selfesteem and confidence. Isaacson ${ }^{33}$ mentions some of the characteristics of an individual that may influence resilience: the ability to bounce back, good-natured personality, responsibility, optimism, problem-solving skills, creativity, morality, curiosity, coping skills, empathy, and religiosity. Studies by Ahmad et $\mathrm{al}^{34}$ and Alim et $\mathrm{al}^{25}$ also show that optimism is related to individuals' resilience in facing stress and alcohol use.

Optimism also serves as a shield preventing former drug abusers from using drugs again. Some previous studies also indicate that there is a significant relationship between optimism and abstinence in drug abusers..$^{35,36}$ The higher the optimism of the drug abusers, the less likely they will use drugs (abstinence). It can be said that convicts with optimism in themselves will find it easy to adapt to their new environment. Thus, they will be able to be responsible for all of their actions and will be spared from stress while serving their sentence. If they have good adaptation skills, they will be able to adapt to their new environment, either in physical, psychological, or social aspects. ${ }^{37}$

Optimism is a vital psychological source for an individual to survive negativity. ${ }^{38}$ An optimistic individual will be able to survive crises, demonstrate a high level of self-efficacy, and adapt to stressors in a more effective manner. ${ }^{39}$ Scheier and Carver ${ }^{40}$ also explain that an optimistic individual will tend to use an effective coping strategy in the face of hardship. How an individual adapts in response to difficulties may influence their resilience. ${ }^{41}$ Optimism is linked to the serotonin in the body. When an individual feels optimistic, the serotonin will be activated and increased. ${ }^{42}$ The increase of serotonin in the body can improve one's mood. ${ }^{43,44}$ In addition, serotonin also influences one's stress response and emotion regulation. ${ }^{45}$

Goleman ${ }^{46}$ perceives optimism from the emotional intelligence standpoint as individuals' ability to motivate themselves while in despair, think positively, and develop optimism in their lives. This ability will enable them to survive the problems befalling them, to keep pushing in the face of major hurdles, not to be desperate, and not to lose hope. Carver et $\mathrm{al}^{47}$ state that optimistic individuals dream to achieve a goal by fighting with all their might. Optimistic individuals do everything by themselves and averse to thinking about failure before trying. They will think of what is best but have the grasp to choose which part is needed as a measure to find the way.

The second factor is self-efficacy. Self-efficacy has also been proven to have a positive influence on adolescents' resilience, meaning that the better the self-efficacy, the higher the resilience. ${ }^{48}$ Research by Narayanan and Onn ${ }^{49}$ revealed that self-efficacy and social support simultaneously contribute to ones' resilience. The higher ones' selfefficacy in solving problems and the higher the social support they receive, the better their ability to overcome adversity. Self-efficacy contributes to ones' ability to face or adapt to challenge and life pressure. Self-efficacy allows individuals to find a way to solve their problems, and, thus, adapt positively to the problems or life pressure. Resilient individuals will be able to bounce back after experiencing hardship. After experiencing and successfully overcoming difficulties, an individual's self-quality and ability will be improved..$^{50}$

When being examined further, self-efficacy is what forms 
resilience in the ability domain (I can). In the 'I can' domain, one should be hopeful, believe in themselves (self-efficacy), and be able to push themselves. In the 'I can' domain, the ability to solve problems such as self-efficacy is needed. A resilient personality is characterized by a belief in oneself (self-efficacy) to manage challenges and life situation effectively. Ergo, self-efficacy is a factor in or prerequisite to resilience. Having an internal control locus, resilient individuals believe that life events are, to a high extent, influenced by their own behaviors. Bouncing back departs from ones' belief that they are able to deal with the problems they are facing..$^{51}$

The last factor is self-esteem. According to Kumpfer ${ }^{52}$ and Masten and Coatsworth ${ }^{9}$, self-esteem is a factor that forms resilience; high self-esteem will form high resilience, while low self-esteem will form low resilience. The results of this research align with those of some previous studies, which indicate that there is a positive relationship between the self-esteem and resilience in adolescents. ${ }^{10,53}$

Covington in Owens ${ }^{54}$ states that individuals with high selfesteem will be more resilient in facing life changes, show higher achievements, and be better socio-emotionally. It is argued that self-esteem serves as an individual's protector against the effects of illness and preventer from various life problems. This notion assumes that individuals with high levels of self-esteem adopt a social attitude that is socially more acceptable and responsible.

Some of the factors closely related to resilience construct are protective factors and risk factors. ${ }^{52}$ Protective factors are needed in resilience to better and protect an individual from unfavorable progress. ${ }^{55}$ According to Masten and Coatsworth, ${ }^{9}$ protective factor contributes to the increase of opportunity for prosocial behavior and norms consistently at all times. McCubbin ${ }^{55}$ breaks down protective factors into two categories: internal and external protective factors. Internal protective factors consist of self-esteem or self-efficacy, while external protective factors consist of family support and environmental engagement.

\section{CONCLUSIONS AND RECOMMENDATION}

Factors which influence drug abusers' resilience are selfefficacy, optimism and self-esteem. These factors may serve as potential targets of the intervention strategy for increasing drug abusers' resilience. Some programs that increase self-esteem, optimism and self-efficacy of drug abusers must be developed and implemented to increase their resilience and prevent relapse.

\section{REFERENCES}

1. BNN RI. Survei Prevalensi Penyalahgunaan Narkoba pada Kelompok RumahTangga di 20 ProvinsiTahun 2015. Jakarta: BNN; 2016.
2. BNN RI. Laporan Kinerja Badan Narkotika Nasional 2015. Jakarta2015.

3. BNN Prop DIY. Laporan Tahunan Badan Narkotika Nasional Provinsi Daerah Istimewa Yogyakarta Tahun 2014. In: DIY BP, ed. Yogyakarta2015.

4. Sekretariat Negara Republik Indonesia. UndangUndang Republik Indonesia Nomor 35 Tahun 2009 tentang Narkotika. Jakarta2009.

5. Afkar A, Rezvani S, Sigaroudi A. Measurement of Factors Influencing the Relapse of Addiction: A Factor Analysis. . International Journal of High Risk Behaviors and Addiction. 2017;6(3):e32141.

6. Snow D, Anderson C. Exploring the factors influencing relapse and recovery among drug \& alcohol addicted women. Journal of psychosocial nursing and mental health services. 2000;38(7):89.

7. Smith R, Ascough J. Promoting emotional resilience: Cognitive-affective stress management training. Guilford Publications; 2016.

8. Zolkoski S, Bullock L. Resilience in children and youth: A review. Children and youth services review. 2012;34(12):2295-2303.

9. Masten A, Coatsworth J. The development of competence in favorable and unfavorable environments: Lessons from research on successful children. American psychologist. 1998;53(2):205.

10. Veselska Z, Geckova A, Orosova O, Gajdosova B, van Dijk J, Reijneveld S. Self-esteem and resilience: The connection with risky behavior among adolescents. Addictive behaviors. 2009;34(3):287-291.

11. Mujeeb A, Zubair A. Resilience, stress, anxiety and depression among internally displaced persons affected by armed conflict. Pakistan journal of social and clinical psychology. 2012;9(3):20-26.

12. Reivich K, Shatte A. The resilience factor: 7 keys to finding your inner strength and overcoming life's hurdles. Harmony; 2003.

13. Pertiwi M. Dimensi religiusitas dan resiliensi pada residen narkoba di BNN lido. 2011.

14. Grotberg E. Resilience for today: Gaining strength from adversity. Greenwood Publishing Group; 2003.

15. Dewi E. Hubungan Antara Dukungan Sosial Dengan Resilience Korban Penyalahgunaan NAPZA Di Panti Sosial Pamardi Putra (PSPP) Yogyakarta, Universitas Gadjah Mada; 2015.

16. Isundariyana H. Hubungan Stres, Strategi Coping, dan Dukungan Keluarga dengan Kecenderungan Penyalahgunaan NAPZA pada Remaja: Fakultas Psikologi, Universitas Gadjah Mada; 2005.

17. Hawari D. Manajemen Stres Cemas dan Depresi: Jakarta Fakultas Kedokteran Universitas Indonesia. 2013.

18. Pavot W, Diener E. Review of the satisfaction with life scale. Assessing well-being: Springer; 2009:101-117.

19. Watson D, Clark L, Tellegen A. Development and validation of brief measures of positive and negative affect: the PANAS scales. Journal of personality and social psychology. 1988;54(6):1063.

20. Palinggi E. Hubungan Faktor Individu dan 
Lingkungan dengan Jenis NAPZA yang Disalahgunakan pada Pasien Rehabilitasi BNN BADDOKA Makassar, Universitas Hasanuddin; 2015.

21. Scheier M, Carver C, Bridges M. Distinguishing optimism from neuroticism (and trait anxiety, selfmastery, and self-esteem): a reevaluation of the Life Orientation Test. Journal of personality and social psychology. 1994;67(6):1063.

22. Simanjuntak E. Hubungan antara Social Support dengan Optimisme pada Orang dengan HIV/AIDS (ODHA). 2011.

23. Gratz K, Roemer L. Multidimensional assessment of emotion regulation and dysregulation: Development, factor structure, and initial validation of the difficulties in emotion regulation scale. Journal of psychopathology and behavioral assessment. 2004;26(1):41-54.

24. Harvey J. Young Men in Prison: Surviving and adapting to life inside. New York: Routledge; 2007.

25. Alim T, Feder A, Graves R, et al. Trauma, resilience, and recovery in a high-risk AfricanAmerican population. American Journal of Psychiatry. 2008;165(12):1566-1575.

26. Williams N. Prison health and the health of the public: Ties that bind. Journal of Correctional Health Care. 2007;13(2):80-92.

27. James D, Glaze L. Highlights mental health problems of prison and jail inmates. 2006.

28. Everall R, Altrows K, Paulson B. Creating a future: A study of resilience in suicidal female adolescents. Journal of Counseling \& Development. 2006;84(4):461-470.

29. Osebe A. The Effects of Imprisonment on Inmates in Kenya: The Case of Industrial Remand and Lang'ata Women's Prisons. : Sociology, University of Nairobi; 2011.

30. Prochaska J, Velicer W. The transtheoretical model of health behavior change. American journal of health promotion. 1997;12(1):38-48.

31. Zamani Z, Nasir R, Desa A, Khairudin R, Yusooff F. Family functioning, cognitive distortion and resilience among clients under treatment in drug rehabilitation centres in Malaysia. Procedia-Social and Behavioral Sciences. 2014;140:150-154.

32. Siebert A. The resiliency advantage: Master change, thrive under pressure, and bounce back from setbacks. Berrett-Koehler Publishers; 2005.

33. Isaacson B. Characteristics and enhancement of resiliency in young people. 2002.

34. Ahmad S, Feder A, Lee EJ, et al. Earthquake Impact in a Remote South Asian Population: Psychosocial Factors and Posttraumatic Symptoms. . Journal of Traumatic Stress. 2010;23(3):408-412.

35. White $\mathrm{J}$, Wampler $\mathrm{R}$, Fischer $\mathrm{J}$. Indicators of spiritual development in recovery from alcohol and other drug problems. Alcoholism Treatment Quarterly. 2001;19(1):19-35.

36. Majer J, Jason L, Olson B. Optimism, abstinence self-efficacy, and self-mastery: A comparative analysis of cognitive resources. Assessment. 2004;11(1):57-63.

37. Crank B. Adapting to incarceration: Inmate perceptions of prison life and adjustment. 2010.

38. Taylor Z, Widaman K, Robins R, Jochem R, Early D, Conger R. Dispositional optimism: a psychological resource for Mexican-origin mothers experiencing economic stress. Journal of Family Psychology. 2012;26(1):133.

39. Hecht D. The neural basis of optimism and pessimism. Experimental neurobiology. 2013;22(3):173-199.

40. Scheier M, Carver C. On the power of positive thinking: The benefits of being optimistic. Current directions in psychological science. 1993;2(1):2630.

41. Benzies $\mathrm{K}$, Mychasiuk R. Fostering family resiliency: A review of the key protective factors. Child \& Family Social Work. 2009;14(1):103-114.

42. Kolb B, Whishaw I. Fundamentals of human neuropsychology. Macmillan; 2009.

43. Escames G, Ozturk G, Baño Otálora B, et al. Exercise and melatonin in humans: reciprocal benefits. Journal of pineal research. 2012;52(1):111.

44. Vina J, Sanchis G, Martinez B, Gomez C. Exercise acts as a drug; the pharmacological benefits of exercise. British journal of pharmacology. 2012;167(1):1-12.

45. Akimova E, Lanzenberger R, Kasper S. The Serotonin-1A Receptor in Anxiety Disorders. Biol. Psychiatry 66. 2009;66:627-635.

46. Goleman D. Emotional intelligence. New York, NY, England. Bantam Books, Inc; 1995.

47. Carver C, Scheier M, Segerstrom S. Optimism. clinical psychological review, 30. 2010.

48. Sagone E, De Caroli M. Relationships between resilience, self-efficacy, and thinking styles in Italian middle adolescents. Procedia-Social and Behavioral Sciences. 2013;92:838-845.

49. Narayanan S, Onn W, Cheang A. The Influence of Perceived Social Support and Self-Efficacy on Resilience Among First Year Malaysian Students. Kajian Malaysia: Journal of Malaysian Studies. 2016;34(2)

50. Ostrowski M, Sikorska I. Health and Resilience. Krakow: Jagiellonian University Press; 2014.

51. Bandura A. Self-efficacy. The Corsini encyclopedia of psychology. 2010:1-3.

52. Kumpfer K. Factors and processes contributing to resilience: the resilience framework.(Ed: MD Glantz ve JL Johnson) Resilience and development: Positive life adaptations. New York: Kluwer Academic/Plenum Publishers; 1999.

53. Balgiu B. Self-esteem, personality and resilience: Study of a students emerging adults group. Journal of Educational Sciences and Psychology. 2017;7(1)

54. Owens T, Stryker S, Goodman N. Extending selfesteem theory and research: Sociological and psychological currents. Cambridge University Press; 2006.

55. McCubbin L. Challenges to the Definition of Resilience. San Fransisco: American Psychological Association; 2001. 